\title{
Systematic Ethnic Cleansing: The Case Study of Rohingya
}

\section{Yousuf Storai*}

International Center for Refugee and Migration Studies (ICRMS), BUITEMS, Pakistan

\begin{abstract}
This paper attempts to analyze the situation in Rakhine state of Myanmar with reference to Rohingya ethnic community. The paper primarily focuses, the state polices of Myanmar's since its inception with Rohingya community. Moreover, the role of counterpart agencies such as major political parties and military are also discussed in the paper. It argues that government machinery as a whole is systematically involved in weakening and expelling the Rohingya community. This systematic weakening is indirectly pushing the said community out from the country, which is called as ethnic cleansing. While the conceptual framework used in the paper is "exclusionary approach/concept" which is derived from the theory of national integration. In addition to this, the study includes structured interviews, which are conducted from international scholars and researchers as well, which are well up on the issue. These interviews also substantiated that Rohingya are frequently subject of abuses as well as persecution by the Myanmar government. Whereas, the purpose of paper is to understand the issue from its core, as it is one of the burning issue, due to which large number of Rohingya are assuming the status of refugee. Thus, the research will play significant role in the policy recommendations/formulations disk with regard to understanding and solving the long disagreement.
\end{abstract}

Keywords: Ethnic cleansing; Rohingya ethnic community; Census; Military crackdowns; Rakhine

\section{Introduction}

"The displacement of hundreds of thousands of members of Myanmar's Rohingya community can only be described as ethnic cleansing" ----- Antonio Guterres.

Mass migration in shape of refugee is one of the emerging issues to the peace and security of the world. Due to it, millions of people across the globe are subject to forced migration in one or the other way. While refugee and migration is most of the time product of inter communal riots, identity crisis, inter religious differences, nationalistic tendencies, plurality, and ethnic conflicts [1]. Moreover, refugee influx also occurs when a state does not equally treat its polarized or heterogeneous society. While, such kinds of persecutions, which have led to migration have long history can be traced back to the end of cold war. In addition to this, countries such as Pakistan, Somalia, Afghanistan, Bosnia, Rwanda, Indonesia, Srilanka and Philippine etc, have largely witnessed such worst kind of exodus migration [2]. Therefore, Asia remains the most discussed region in the debates related to migration and refugees disagreement.

The same is the case of Rohingya; a Muslim ethnic group, living in the western side of Myanmar, which is Rakhine, previously called as Arkan. This ethnic group, which constitutes $4 \%$ population in Myanmar, is living in miserable conditions and their source of income is largely dependent upon fishing and agriculture [3]. Moreover, their dominated areas are totally deprived off basic necessities of life, while the poverty rate in the area is 78\% [4]. Not only this, these people are having no legal documents, the government does not own these people and consider them as refugee in Myanmar. Based on immigrant or refugee status, they are often made scapegoat of every ill, while sometimes they are blame for having links with armed groups, which occasionally attack the law enforcement agencies. In addition to this, Rohingya do not have role in the state building process as well as in the institutions of the state. While on other hand, sporadically clashes flares up with other communities in the country, notably with Buddhists. Therefore, each such clash mounts violence and gives birth to persecutions of Rohingya, in shape of death, injuries, hate, burning of property etc. As a result, such kind of violence further enlarges the gap of mistrust between Rohingya and Buddhists. So, these unending and unexpected waves of persecution, force Rohingya to take shelter in the state sponsored camps (Inside Myanmar) as Internally Displaced Persons (IDP's), while others fly to the neighboring countries of Myanmar. In short, due to the recent unrest in Myanmar, which sparked in August 2017, have made more than 600,000 Rohingya to left their homes and have taken refuge in Bangladesh only [5]. Therefore, the connecting dots shows that major state actors are systematically involve in the weakening and purging of Rohingya out from the country. Thus, due to this systematic weakening, the Rohingya community in Myanmar is often subject of mass migration.

The primary cause of violence against Rohingya is the unsettled questions, which is regarding their identity and origin. At present, the Myanmar government does not accept these people as their citizens or nationals. The government believes that Rohingya are illegal immigrants, living in the country from long ago. Even the government has classified them as Bangladeshi, it is because Myanmar government opinions that these Rohingya share similar physical and cultural characteristics/traits with the people of Bangladesh. Further, government also endorses that their ancestors had migrated from Bangladesh and settled in Rakhine state during the British colonial rule [6]. While on other hand, Bangladesh government refutes the claims of Burmese government and condemns the later government, for the use of force against the Rohingya people. In fact, it was the Ne Win regime (1962-1988), which enacted the Emergency Immigration Act in 1974, according to the act Rohingya were declared as foreigners, consequently they lost their national identity [7]. Thus, the government considers Rohingya as illegal immigrants, so for this reason most of the time government has adopted very anti approach in dealing them.

*Corresponding author: Yousuf Storai, Research Fellow, International Center for Refugee and Migration Studies (ICRMS), BUITEMS, Pakistan, Tel: +92 (81) 2880410; E-mail: yousuf.icrms@gmail.com

Received April 04, 2018; Accepted April 11, 2018; Published April 18, 2018

Citation: Storai Y (2018) Systematic Ethnic Cleansing: The Case Study of Rohingya. Arts Social Sci J 9: 357. doi: 10.4172/2151-6200.1000357

Copyright: (c) 2018 Storai $Y$. This is an open-access article distributed under the terms of the Creative Commons Attribution License, which permits unrestricted use, distribution, and reproduction in any medium, provided the original author and source are credited. 
Generally, people belonging to Buddhists community in the country assume that Islam is an emerging threat to Myanmar. They fear that this community is infusing their ideology in the country, which with the passage of time will ultimately overshadow their state religion. Their fear is because, there are some armed groups, which are operating within the country and most of the time, found in terror incidents. Therefore, to justify their threat from Muslims Buddhists put the example of Rohingya Solidarity Organization (RSO); it is an armed organization of Muslims, which has taken the responsibilities of several coordinated attacks, in which Myanmar security personnel's have been targeted. Further, they believe that Rohingya are also having links with some global Jihadi organizations, whose aim is to promote Jihad in Myanmar against Buddhists somewhat like that, which is going in Afghanistan. So, based on the perceived threats to their religion, Buddhists since long are purposefully trying to get rid of Rohingya [8]. Therefore, to shape their desired aims, these groups regularly hold anti Rohingya protests, sit in and rallies in the country. Primarily their objectives by doing so, is to fuel hatred feelings against the persecuted minority group. Secondly, they act as pressure groups on government and finally they are shaping public opinions against Rohingya community.

The Myanmar's government has completely adopted the policy of marginalization with respect to small ethnic groups, living in the country. These small groups include the Muslims of Rakhine state, which constitutes somewhat $68 \%$ population in Rakhine and is highly affected from the state policy [9]. Whereas the policy of marginalization has been practicing since long ago. Due to this, Rohingya are deprived from education, property rights, marriage, employment, free movement (travel) and other essentials of a society.

This research paper attempts to investigate Rohingya migration from Myanmar. It examines the causes of Rohingya Mass migration from Myanmar and determines the role of Myanmar's government with regard to Rohingya migration. Therefore, this study will be helpful for building consensus and understanding the unsettled issue from various perspectives. In addition to this, the study will be useful for policy makers concerning Rohingya issue. Finally, yet importantly, it will act as baseline information for researchers as well as to students in future. This study is qualitative in nature, whereas semi-structured interviews are conducted from researchers and academicians. While thematic analyses is employed to analyze the data. The study is guided with the political philosophy of "Social Exclusion" as it helps to analyze the causes, effects and role of counter-parts involved in the conundrum.

\section{Land and People of Myanmar}

Myanmar is an Asian country with a long history, which could be trace from the ancient Pagan Kingdom of 839 [10]. The modern Myanmar liberated itself from the British colonial rule in 1948. The capital is Naypyidaw, population is 52.89 million people and area is $676,579 \mathrm{Sq} \mathrm{km}$. It borders with China, India, Laos, Thailand and Bay of Bengal [4].

The country is having a parliamentary system with a bicameral legislature. In addition to this, the country is divided into somewhat 14 administrative units. Furthermore, Myanmar is an ethnically much diverse country with officially 135 recognized races dwelling in it, while few are unrecognized like Rohingya. The ethnic breakdown in the country is, Burman's $68 \%$, Shan $9 \%$, Karen $7 \%$, Rakhine $4 \%$, Chinese $3 \%$, Indian $2 \%$, Mon $2 \%$ and $5 \%$ other. While on other hand, Buddhism with $87 \%$ is the largest religion in Myanmar, second comes Christianity $6.2 \%$ and then Islam with $4.3 \%$ [11]
Arkan is one among the fourteen states of Myanmar, the very word Arkan is an Arabic word, derived from Rukn, which is singular, and it literally means "a pillar". The word Arkan highlights the five fundamentals of Islam, so it means, a place where five pillars of Islam is follow. So, the word Arkan became popular for the region, when Muslims conquest it, somewhat around $1430 \mathrm{AD}$ [10]. There are two major ethnic communities, which are dwelling in the Arkan state, the Rohingya, who are Muslims, while the Maghs/Rakhines with Buddhist religion

Although both communities were living without any territorial demarcation but after the antiMuslim riots of 1942, the Maghs moved towards the southern and Rohingya to the northern side of the Rakhine state. In addition to these two ethnicities, some other minority tribes like Chaws, Saaks, Mros, and Kons are also living in Arkan.

Arkan state is located in the north west of the country, which is comprised of somewhat 20,000 square miles. Arkan has 369 miles coastal belt with Bay of Bengal, and geographically it is a mountainous narrow strip of land, most of the land is cover with thick forests, creeks and rivers are largely present [10]. The said state has 176 miles border with Bangladesh, separated by one of the seven rivers of the province called river Naf, while Arkan Yoma mountain range divides it from rest of the Myanmar [12]. On other hand, it has border with India too. This is the only Muslim majority province in the country, where out of the total 7 million Muslim population, half live in the said province.

\section{A Short History of Rohingya}

The available literature traces the history of Rohingya somewhat from $8^{\text {th }}$ century, where they were living in an independent kingdom called Arkan, the present day name for Arkan is Rakhine [13]. While the people of Arkan state came into a contact with Islam between $9^{\text {th }}$ to $14^{\text {th }}$ centuries through Arab traders, which sailed for trade purposes from Bengal to Arkan. Meanwhile, strong relations developed between the people of Bengal and Arkan state. In 1784, the then army of Burman King Bodawpaya captured Arkan and ruled it in a very tyrannical manner; as a result, thousands of Rohingya fled to Bengal and established a town. Later on, in 1790 British Diplomat, Hiram Cox was send to the said town to assist Rohingya refugees and the town was later named after him. Event today large number of Rohingya are living in Cox bazar [14]. Interestingly, Arkans politics entered into a new phase in 1824, when British captured Myanmar and made it part of United India. While during the Second World War, Japan invaded and pushed out British forces from Burma in 1942, with the retreat of British from Myanmar, Burmese attacked Muslim community because they viewed that Muslims benefited and privileged during colonial rule. After period of three years, British again retook Burma with the help of Rohingya and Burmese nationalist's fighters which led by Aung San. On the other hand, Rohingya were promised by British, that an independence status of Arkan state would be restored at the time of granting independence to Burma but British retreated and declared it as a province of newly independent state in 1948. However, Rohingya resisted against this design and wanted an independence status for their state; this was in fact the first point from where gulf emerged between Rohingya and other communities of the Myanmar. Meanwhile Rohingya showed themselves as a rebellious, while government decided to supress them. The first punishment on the behalf of government was seen as the remove from civil services. Later on in the year 1962 General Ne Win of Burma Socialist Programme Party took over the government, he too adopted very stern approach in dealing with Rohingya [6]. After few year rule of military junta General Ne Win in 1977, launched operation 
Dragon King, which was basically aimed to expel Rohingya out from the country. As a result of that operation somewhat 200,000 Rohingya fled to Bangladesh. So, during that mass exodus Rohingya largely blamed army for abuses, whereas army denied the allegations and wrongdoing. Furthermore, in 1982, new immigration law was acted out in Burma, which declared all those people illegal, who had migrated to Burma during the British rule [6].

In 1991, once again, the wave of violence against Rohingya in Rakhine soared up, where people became victim of rape and forced labour at the hands of Myanmar army, more than 250,000 Rohingya were driven into other countries as refugees [15]. Later on, the violence abated due to the repatriation deal, as a result 230,000 Rohingya had returned to Arkan state by 1997. However, the serenity in Arkan did not last long, as the violence in the state is spasmodic in nature. So in 2012 again ethnic riots between Rohingya and Buddhists reached its peak, in which more than 100 people were killed and again tens of thousands of people migrated to Bangladesh while hundreds in to internally displaced camps [16]. Later on in the year 2016 September, another cycle of violence broke out in, when Harakal-al-Yakin armed group attacked the post of border guards, in that incident nine solders were not only killed but also looted of their weapons. As usual, the government blamed Rohingya for the act and stated that that the group is harbored by them.

As cited, earlier that Rohingya conflict is spasmodic in nature or it is not going to end. Therefore, the latest violence sparked off on $25^{\text {th }}$ of August 2017, when eleven soldiers were killed by the attack of armed men in the South of Maungdaw (Rakhine main northern town) [17]. The responsibility of the attack was carried by the Arkan Rohingya Salvation Army (ARSA); it was previously called as Faith Movement/ Harkat-ul-Yaqin. With this government once again got an excuse and launched crackdowns against Rohingya. Thus, due to persecutions, so far more the 6,00,000 Rohingya have been fled from Rakhine to the other neighboring countries of Myanmar [18].

\section{Theoretical Framework}

National integration is in fact a very complex phenomenon. It is because unifying contrasting identities or poly ethnic societies under one government is really difficult because all groups want equal considerations in terms of cultural, economic, language, customs and political aspirations. So national integration is basically talks about the importance of balance among the heterogenic societies. Whereas, it is the prime duty of a state to build social cohesion by balanced policies [19].

National integration is a broad term and is addressed by the modernist and post-modernist school of thoughts. Generally, both postmodernist and modernist talk about national integration but in quite different ways. While the leading exponents of modernist approach are Karl and Vetik. They believe that national integration is possible only through an "assimilatory approach". Whereas assimilatory approach talks about policies which focuses on uniting various ethnic communities into a single entity, which transfer their loyalties to state. Moreover, one can example of democratic multiculturalist states, where perfect integration exists. Further, this school of thought views that an assimilation is the precondition for the smooth socio economic development of a state. So, such polices which lay stress over the force of cohesion in a society is simply an assimilatory approach. While on other hand as critique to this, post-modernists emerged led by Walker Connor. They expressed that assimilation policy is detrimental threat to the process of national integration. They argue that if state uses force to assimilate a minority group into a majority, then there is chances that such state could face ethnic war and turbulence [20]. Therefore, they believe that national integration could be maintain by "exclusionary approach" only. Whereas, they view that conflicts in a state could be resolve and manage only by the process of eliminating ethnic minorities from state. Exclusionary approach includes policy of segregation, not allowing minority groups to allow in the affairs of state, delineating them culturally and religiously. In addition to this a state in the pursuit of exclusionary approach never takes an initiative to accommodate minority groups neither does pay heed towards their concerns [21]. So, with regard to practice of this approach, one can recite the example of Rwanda between 1990 to 1994, where it was largely carried out, due to which roundabout 800,000 people became victimized of it. Second, the policy of apartheid, which was practiced in South Africa for a long can also be cite in this regards [22].

\section{Burma registration Act of 1949}

Right after Myanmar's independence in 1948, the government regarding authentic documents of citizenship, enacted the Burma Registration Act in 1949. According to this act, all people of the country were required to registered themselves. For this, there were only two categories of certificates/documentations, which were given to them. The first was National Registration Cards (NRCs), these cards were given to residents of the country, while the second was Foreigner Registration Certificates (FRCs), which were to foreigners respectively [23]. So according to this act, Rohingya were given National Registration Cards and declared as citizens of the state. Whereas on the basis of NRC's, Rohingya had received National passports and traveled abroad especially to Makkah as pilgrims [24]. Therefore, under international law, possession of passport or any other such document is the proof of nationality. Not even this, for several years Rohingya, on the basis of these cards elected members of Pyithu Hluttaw (House of the representatives).

While Ronan Lee describes the origin of Rohingya, as they are an overwhelmingly ethnic minority group, which often describe themselves as a Rohingyan Muslim, they have a heritage in Myanmar living there from hundreds and hundreds of years. Rohingya have a distinct ethnic identity and conflict at the movement is the result of decade of systematic ethnic abuse by Myanmar government predates back to British colonial era [25].

\section{Citizenship law of 1982 and Rohingya}

Things became completely worsen, when in 1982, Myanmar's government under the leadership of $\mathrm{Ne}$ Win, took its first step to push Rohingya towards identity crisis. It was basically the enactment of Citizenship Law of 1982. According to law, there were three types of citizenships; Full, Associated and Naturalized citizenship. Whereas the said law further highlighted that, Full citizenship is granted only to those people, whose ancestors had been settled in Myanmar, prior to the first British occupation of the state in 1823 [9]. While the eligibility criteria for the Associated citizenship is that, persons who had entered and resided in Myanmar before January, 1948. In addition to this, Naturalized citizenship is given to those individuals who can provide "conclusive evidence" and had entered Myanmar prior to 4 January 1948. So, almost all the Rohingya have been resident in Burma for that period of time and even people who arrived after Burmese independence of 1948, now their grand and grand children's will be entitled by citizenship but what is happening now is that the authorities of Myanmar are refusing to properly assess the citizenship claims of any, who says that they are Rohingya. Therefore, they are denied 
both the claim of Residency as well as of indigenous citizenship. So, Myanmar is not applying its law in a fair way [25]. On other hand Ronan also believes that "government has excluded Rohingya from the list of ethnic groups that are consider as indigenous. Myanmar says that residency prior to 1823 entitles the group to be consider indigenous than the Rohingya are surely entitled to that right now that's been denied to them by the authorities and the authority treat them as they are migrants from other country and not entitled to the citizenships rights that they should have. Their rights with in the

Myanmar is badly restricted" [25]. So in this way Rohingya were excluded from the Full, Associated, as well as Neutralized citizenship [23]. Thus, it is racism and religious prejudice due to which Myanmar does not consider Rohingya as their indigenous citizens [25].

\section{Role of military and Rohingya}

Military is one of the main actor in Myanmar and its role in politics cannot be undermined. Whereas it entered in the politics of the country right after few years of the independence and continued ruling country till the year 2010. Generally, military do not have a satisfactory record in terms of relations with civilians. The minority groups living in the country always criticize military for maltreatment towards them, similarly Rohingya is also one of the main ethnic community to whom military have adopted very anti approach.

When asked that why Myanmar's army have adopted a very punitive approach towards Rohingya?

She stated that "I disagree with the military's approach to the Rohingya and believe that they should grant citizenship to native born Rohingya and stop discriminating against them" [26].

In fact, Military in Myanmar do not only want to run the country, they also want to maintain their current position in the country. Therefore, they are trying to slow down the process of reforms, because to remain in touch with the certain benefits and privileges, which they are enjoying since 1962 [27]. On the basis of this, experts view that in fact, military is the real power in the country's politics, on other hand the political parties are having very nominal role. So, if one talks about its approach towards people of the country, one would not be wrong to say that military have adopted overall very stern approach in dealing with the masses. Military is also pursuing a long-term strategy to consolidate political support and control by scapegoating the Rohingya and promote a form of Burmese nationalism centered on Buddhism [26].

Whereas the military of country is led by Min Aung Hlaing, who is the commander in chief of the army. He has so far, launched several military operations against Rohingya, with the pretext of eliminating militants, who attacks government institutions for example, police stations. During the latest spark of violence that erupted in 2017, the commander in chief on his Facebook account also refused to accept Rohingya as their indigenous citizens. He has used the word "extremist Bengalis" to Rohingya [28]. Not only this, military have been accused of heinous crime and atrocities such as rape and gang rape. The special envoy of United Nations, Pramila Pattern, who had visited the camps of Rohingya in Cox Bazar, said that the country soldiers had "Systematically targeted" Rohingya women for sexual violence during the ethnic clashes. She further adds that the incidents of gang-rape compelled Rohingya to migrate to Bangladesh. "I heard horrific stories of rape and gang-rape, with many of the women and girls who died as a result of the rape," Patten told to media in Dhaka [29].
United Nations Humans Rights Council (UNHRC) have too criticized the Min Aung Hlainga and his army for deliberately targeting Rohingya in the Rakhine state and stated that the army have adopted a policy of "systemic discrimination" towards the Rohingya. While in particular, Min Aung Hlainga is accused of ethnic cleansing and human rights violations [30]. This news came to lime light, when Human Rights Watch released satellite images, which showed that 62 villages had been arson between August to September of this year, some villages partially and others were completely destroyed. In this regard the Human Rights Asia Director Phil Robertson has said, "Our field research backs what the satellite imagery has indicated - that the Burmese military is directly responsible for the mass burning of Rohingya villages in northern Rakhine State" [31]. Therefore, such an act of arson is ultimately forcing the Rohingya residents to flee. Furthermore, this says that it is an indirect tactic to ethnic cleansing [32].

\section{Operation King Dragon (1978)}

Operation King Dragon king also known as Naga Min was launched by Burmese military in the year 1977 in collaboration with the immigration department of the country [33]. Government claimed that it was an effort to screen and register people before the upcoming national census, further to disarm the members of Rohingya Patriotic Front (RPF) from the area. The RPF was a group of armed Rohingya in Rakhine state. However, it was a lame excuse and aimed to expel Rohingya from the country. So, this operation continued for five months, in which more than one thousand army personnel participated in it. The operation pushed between 200,000 to 250,000 Rohingya from Myanmar to Bangladesh [34]. These migrated people were temporarily sheltered in the camps of Cox's bazar [35].

Meanwhile United Nations High Commissioner for Refugee (UNHCR) declared these migrated people as refugees and urged the government of Bangladesh to establish refugee camps for them.

Thus, these refugees were part of the military's ethnic cleansing campaign

\section{Operation Clean and Beautiful Country (1991)}

This operation was the second push to Rohingya from Myanmar. The Operation Clean and Beautiful country was also known as Operation Pyi Thaya, started in 1991 and was conducted by Myanmar army in the northern Rakhine state between 1991 and 1992. Once again, this operation resulted the migration of somewhat 200,000 Rohingya to refugee camps in Bangladesh. Thus, it was another attempt to purge out Rohingya out of the country [36].

\section{Operation clearance (2017)}

In August 2017 armed men launched coordinated attacks over the security posts in Myanmar. In those attacks, somewhat 12 security officials were killed. While on other hand the responsibility of the attacks was taken by the armed group, which is called as Faith Movement or Arakan Rohingya Salvation Army previously known as Harakat ul Yaqeen [37]. In response to that, Myanmar government decided to launch operation against them [38]. Whereas it was viewed that Rohingya are giving protection to these armed people. However, when asked about armed group, the answer was that an armed group called the Arkanese Salvation Army (ARSA) is present but there is no evidence to indicate that this armed group represent or have the support of the broader Rohingya population in Myanmar [26]. So it again paved the way for violence in Rakhine state between Rohingya 
and Buddhists. Due to which thousands of Rohingya women and children fled from and made their way to Bangladesh as unwanted migrants [39]. According to the UN reports, more than 600,000 Rohingya have been migrated to Bangladesh only, since August. Even still migration is going on [40].

\section{National League for Democracy}

National league for democracy founded in September 1988, right after the 8888 uprising. It is the one of the liberal democratic platform in Myanmar, which advocates nonviolence towards multiparty democracy, national reconciliation and rule of the law. The NLD party was formed by Aung San Suu Kyi and had played very important role in the pro-democracy movement of the country [41]. The party participated in the country's 1990 parliamentary elections and won 392 seats out of 492, on other hand the governing National Unity Party merely won 10 seats [42]. It was generally expected that the party will assume the office of Prime Minster, but the ruling Junta refused to hand over power to the party in order to form government in Myanmar. Not only this, government also started arresting members and crackdowns over the offices of NLD. Whereas large number of members fled from the country while others were put under house arrest. As a result of this, the exiled members of the party formed National Coalition Government of the Union of Burma (NCGUB) in December 1990, with its headquarter in New York, USA. Later on, after period of somewhat 10 years, finally in 2001 the government allowed NLD to reopen their officers throughout the country. However, despite of it, the blinds man's bluff continued for several years between government and the members of NLD. During this period, dozen of the party members were shot down and some resigned due to pressure and harassment from armed forces (Tatmadaw) [43].

General election was held in the country in November 2010 but NLD boycotted because many of its members were not allowed to stand. While on other hand a splinter group emerged from NLD and which was National Democratic Front, it participated in the elections and secured only $3 \%$ votes. That time a newly formed party known as Union Solidarity and Development Party won the election with landslide victory. It was largely stated that military backed USDP in winning the election. Finally, after a series of negotiations, several of its members were freed an NLD re register itself in 2011 [44]. The next year in 2012, again general election was held, in that election NLD won 4 seats and assumed the role of opposition in the parliament. During this period party made their position and the people of Myanmar in confidence as a result of this, the party won the general election of November, 2015 with landslide victory in the both houses [45]. Thus, NLD formed majority government under the leadership of Aung San Suu Kyi as the first state counsellor of the Myanmar. The party is in the government for last two years, However, it has taken no practical steps for the solution of Rohingya issue. Even Rohingya is facing the worst type of migration since last August. While their hopes for having a peaceful atmosphere in Rakhine in the government of NLD tarnished away. So, the present government rather than providing protection to the affected community is having allegations of supporting the groups, which persecutes Rohingya.

\section{Aung San Suu Kyi and Rohingya}

Aung San Suu Kyi, which is an idol for democracy both inside and outside the Myanmar. She emerged as political activist in 1988 during anti-government uprising. Based on her struggle for democracy and personification of democratic ideals, she has been awarded with Nobel Peace prize in 1991 [46]. In addition to this, she had served in the opposition in the past, while currently in majority in both houses of the country and serving as first state counselor of the country, which is as similar in power to Prime Minister. While Aung San Suu Kyi has been totally silent over the ongoing persecutions of Rohingya, since she is in power. Whereas her silence is causing significant discomfort to the international rights community. However, indicators show that she does not consider it as pressing issue. It is because on several occasions she has denied that ethnic cleansing of Rohingya are taking place [47]. In a latest interview with $\mathrm{BBC}$, which was given to Fergal Keane on $5^{\text {th }}$ of April 2017, he asked Aung San Suu Kyi,

Do you ever worry that you will be remembered as the Campion of human rights, the Nobel laureate, who failed to stand up to ethnic cleansing in her own country?

"No because I don't think that ethnic cleansing is going on, I think ethnic cleansing is too stronger and expression to use what is happening. Fergal, I think there is a lot of hostility there and as I pointed out, its Muslims killing Muslims as well if they think they are collaborating authorities, so it is not a matter of ethnic cleansing as you put it, it is matter of people on different sides of a divide and this divide we are trying to close up as best as possible and not to widen it further.

There are few reasons due to which Aung San Suu Kyi is silent over the conflict, first is the political calculation or the popular Burmese sentiments against the Rohingya, Second She is partner with the military in the current government and last is that she herself believes that Rohingya are not a rightful part of Myanmar's ethnic composition [26]."

So, Aung San Suu Kyi is button up on Rohingya migration out from the country. Further, she has not even made a clear statement over the ongoing communal violence. In fact, it is of various factors, the primary factor is of domestic electoral politics. Because the country for most of the time had been run by military due to which people are now fed-up of military rule, so keeping this factor in mind, she thinks that her party is having a bright future in the country. With this aim in mind, she avoids any steps regarding the issue, which endangers her popularity among the voters.

That is the population of ethnic Burman's, which is comprised of $65 \%$ as compared to Rohingya, which is only $4 \%$. Therefore, she is playing cards with shrewd calculation avoiding any such step or comment that could alienate her party from $65 \%$ voters, on which the future of her party is dependent. In this respect, Muslims and the other reminder ethnic groups do not have much importance in the political sphere of Myanmar. Furthermore, a group like Rohingya, which even do not have identity and subject of statelessness, have any importance or say in the country? Thus due to political reasons or interests she is willfully overshadowing Rohingya issue since long [46].

\section{Union Solidarity and Development Party}

The Union Solidarity and Development Party is one of the political party, which is having greater role in the mainstream politics of Myanmar. The USDP registered in 2010 and is extension of Union Solidarity and Development Association. The party won the election of 2010 with landslide victory and formed the government. While in the next election of 2015, USDP emerged as the second majority party and currently assuming the role of opposition in the parliament. The party does not have any member from Rohingya ethnic group [26]. Even though Union Solidarity and Development Party (USDP) led a coalition of somewhat 20 political parties; they signed the statement and put forward four demands. Which were; provision of tight security to government officers, enforcement of 2014 counter terrorism 
law, improving the general security of the region, rejecting the term Rohingya and using the term "Bengali" for them. They stated that they are migrants from Bangladesh, therefore labelled them as Bengalis, throughout the country [48]. This action of USDP greatly upset the Rohingya ethnic group of Myanmar. Not only this, a referendum as well as second competitive parliamentary elections in the country were held in 2015, everyone was allowed to participate and cast vote. On other hand thousands of Rohingya have had their names in that list but Buddhists and other monk's groups came out in the streets and demanded the government not to allow Rohingya to participate in it. A Buddhist monk

Shin Thumana, who was in the protest viewed that "White card holders are not citizens and those who are non-citizens don't have the right to vote in other countries" and further adds "This is just a ploy by politicians to win votes." [49]. Therefore, that protests once again sparked violence between Buddhists and Rohingya across the country. Because of those protests, USDP deprived Rohingya from casting votes. Thus, it declared more than one million ethnic Rohingya as non-citizen of the country by not allowing them to vote.

\section{National Census and Rohingya}

National census is one of the important element for the prosperity and development of a state. The very word census means "a periodically, systematic process of recording and acquiring information about population in a state". The government of Myanmar has so for conducted only few national censuses in the country. Prior to the census of 1983, government of Myanmar introduced the Emergency Immigration Act of 1974. That act officially deprived Rohingya people from the citizenship rights, in addition to this government then launched Operation Nagamin. The said operation was aimed to expel Rohingya community indirectly from the census, which was going to be held in the upcoming years. So, before lunching operation, government alleged Rohingya for supporting the armed groups. Therefore, this was an excuse for government to start operation against Rohingya. So the said act as well as the operation paved the way for the census of 1983 in which Rohingya were not counted [50].

Whereas the last census took place in collaboration with $\mathrm{UN}$ in the year 2014, in fact it was conducted after a period of 30 years. In that census, the Rohingya ethnic group was allowed to participate in it, but the Buddhists monks and other nationalist's groups warned the government that they would boycott the census if Rohingya were allowed to identify themselves with the same tag. As a result, the government gave the option to Rohingya to register themselves as "Bengali" only, otherwise they will not be counted in census [39] So,

Rohingya were unable to participate unless they voluntarily identified as "Bengali" [26]. As a result, Rohingya registered themselves as temporary citizens and were granted white cards. However, in February 2015, government took the decision and repelled the white cards of Rohingya. Thus preventing them to vote in the general election as well electing their member [51-54]. Thus, not allowing Rohingya to national census and election in Myanmar means that government is denying their rights. Furthermore, it again clarifies that state is not ready to accept them as their indigenous citizens [55-58].

\section{Conclusion}

Thus, the policies adopted by Myanmar government with regard to Rohingya ethnic group show that, they are systematically purging out them from the country. Whereas the interviews and historical narratives both show that Rohingya are living in the country for generations $[59,60]$. Moreover, it is also a fact that they are from Myanmar rather than India or Bangladesh. However, despite the fact they are denied from the right of citizenships as well as the other basic needs of life. Although after independence for some years Rohingya were declared as citizens of the country but later on, there hard days begun, chiefly when government under the leadership of $\mathrm{Ne}$ Win started came to power $[61,62]$. Since then, the government and other counter parts adopted an exclusionary approach towards the said ethnic group. While operation Dragon king was in fact the first practical step taken by the state towards them, what we call it ethnic cleansing. Furthermore, with the passage of time several other military escalations against Rohingya have been taken place such as Operation Clean and beautiful country and the recent one which started in 2017 is called Operation Clearance. The primary aim of all these operations is to punish them to a larger level because in each operation thousands of Rohingya migrated from the country and assumed the status of Refugee. While at present huge number of Rohingya refugee are living in the camps of Bangladesh's Cox bazar. Besides the punitive approach of states military towards Rohingya the political parties are also having contribution in the conflict. It is because none of the party consider the ongoing persecution as an issue even they had demanded from the government not to allow them in the census. Apart from this, they consider Rohingya as migrants from Bangladesh. While Aung San Suu $\mathrm{Kyi}$, who is consider as the champion as well as the icon of democracy is also silent over the long disagreement. She has not so far taken effective steps for the solution or normalization of the tense relations between Rohingya and Buddhist community [63,64]. It is believing that her silence over the issue is because of vote bank and ethnic composition of the country. While on other hand in 2014 Rohingya were not allowed to participate in the nationwide census, it was again blow to their rights. Later on, in the next year election was in Myanmar again the said group was not allowed to cast their vote. So, this shows that state with other actors are punishing Rohingya and their primary aim by doing so is to expel them out of the country. Therefore, preventing them from participating in voting process, scapegoating them for any ill and then launching military crackdowns against them is the signs that state is pursuing special tactics to get rid of these populations. Besides this the persecution such as arson, mob killing, torture, rape of Rohingya by the hands of Buddhists and other groups is unexplainable. Thus, these tactics by which, they are denied of their rights are directly compelling them to flee from the country is academically known as ethnic cleansing.

\section{References}

1. Fiddian-Qasmiyeh E, Loescher G, Long K, Sigona N (2014) The Oxford Handbook of Refugee and Forced Migration Studies. London: Oxford University Press.

2. Migration and Remittances (2016) Factbook. Washington: International Bank for Reconstruction and Development.

3. Special Issue on Growing Poverty (2016) Independent Journal of Burmese Scholarship.

4. Dutta PV (2015) Risks and vulnerabilities along the life cycle: Role for social protection in Myanmar. World Bank Group Social Protection and Labour 24.

5. Rohingya refugees have been fleeing violence in Myanmar at a staggering rate - and the numbers keep growing (2017).

6. Nemoto K (1991) The Rohingya Issue: A Thorny Obstacle between Burma (Myanmar) and Bangladesh. Journal of Burma Studies, pp: 1-5.

7. Kipgen N (2014) Ethnicity in Myanmar and its Importance to the Success of Democracy. Ethnopolitics. pp: 19-31.

8. O'Hara EB (2015) The Rohingya and Islamic Extremism: A Convenient Myth. 
9. Holliday I (2010) Ethnicity and Democratization in Myanmar. Asian Journal of Political Science, pp: 111-128.

10. Younas DM (1994) A History of Arakan (Past \& Present). Chittagong: University of Chittagong.

11. Kiener R (2012) Myanmar's New Era, Will the military allow reforms to continue? C Q Researcher, pp: 329-352.

12. Tha MT (2007) A Short History of Rohingya and Kamans of Burma.

13. Ullah AA (2011) Rohingya Refugees to Bangladesh: Historical Exclusions and Contemporary Marginalization. Journal of Immigrant \& Refugee Studies, pp: 139-161.

14. Dulal AO (2017) Timeline: Being Rohingya in Myanmar, from 1784 to Now. The Wire.

15. Aung GV (2017) The Contentious Politics of Anti-Muslim Scapegoating in Myanmar. Journal of Contemporary Asia, pp: 353-375

16. Parnini SN (2013) The Crisis of the Rohingya as a Muslim Minority in Myanmar and Bilateral Relations with Bangladesh. Journal of Muslims Minority Affairs. pp: 281-297.

17. Ratcliffe $R$ (2017) Who are the Rohingya and what is happening in Myanmar?

18. Edroos F (2017) ARSA: Who are the Arakan Rohingya Salvation Army?

19. Integration of Second Generation (2008) Russians in. Tallinn: Institute of International and Social Studies, Tallinn University.

20. Connor W (1972) Nation-Building or Nation-Destroying? World Politics, pp: 319-355.

21. Loury GC (1999) Social Exclusion and Ethnic Groups: The Challenge to Economics. The Annual World Bank Conference on Development Economics), pp: $1-41$.

22. Hashmi RS (2014) Ethnic Politics: An Issue to National Integration. South Asian Studies, pp: 345-361.

23. Simbulan KP (2012) A Legal and Structural Analysis of the Violence in Rakhine State Aganist the Rohingya Muslim in Myanmar.

24. Kipgen N (2013) Conflict in Rakhine State in Myanmar: Rohingya Muslims' Conundrum. Institute of Muslim Minority Affairs (IMMA), pp: 298-310.

25. Lee R (2017) A Systamatic Ethnic Cleansing; The Case Study of Rohingya.

26. Activist AA (2017) A Ethnic Cleansing; The Case study of Rohingya.

27. Tarabay J (2017) Myanmar's military: The power Aung San Suu Kyi can't control.

28. Mckirdy E (2017) Bangladeshi prime minister condemns Myanmar over Rohingya treatment.

29. Myanmar soldiers systematically gang-raped Rohingya women: UN envoy (2017).

30. Farmaner M (2017) Only One Person Can Stop Ethnic Cleansing In Myanmar, And It Isn't Aung San Suu Kyi

31. Burma: Military Tourches Homes Near Border (2017).

32. Alam, J (2017) Rohingya Muslims in Bangladesh watch their homes burn across the border in Burma.

33. Hussain S (1978) Rohingya Refugee in World Press.

34. Rahman KM (2015) Ethno-Political Conflict:. International Journal of Humanities and Social Science Studies, pp: 288-295.

35. Selth A (2009) Burma's Muslims \& the War on Terror. Studies in Conflict \& terrorism.
36. Constantine G (2017) Bangladesh The Plight of Rohingya.

37. Myanmar: What sparked latest violence in Rakhine? (2017)

38. Mahmood M (2017) The Rohingya Crisis: History and Politics. Institute of Strategic Studies, pp: 1-5.

39. Albert E (2018) The Rohingya Crisis. Retrieved from Council on Foreign Relations.

40. (2017) Mission Report of OHCHR Rapid Response Mission to Cox's Bazar Bangladesh. UNHCR.

41. Farrelly N (2013) Discipline Without Democracy: Military Dominance in Post Colonial Burma. Australian Journal of International Affairs, pp: 312-326.

42. Guyot JF (1991) Myanmar in 1990: The Unconsummated Election. Asia Survey. pp: 205-211.

43. (1990) Hold on to Peace. Bankok: All Burma Students Democratic Front.

44. (2011) Burma's 2010 Election: A Comprehensive Report. New York: Burma Fund UN Office.

45. Cook AD (2017) Myanmar's National League of Democracy From Opposition to Office one Year On. Rajaratnam School of Intenational Studies, pp: 1-4.

46. Lee R (2014) A Politician, Not an Icon: Aung San Suu Kyi's Silence on Myanmar's Muslim Rohingya. Islam and Christian-Muslim Relations, pp: 321 333.

47. Rieffer L (2017) No Simple Solution to Rohingya Crisis in Myanmar.

48. Aung, TT (2017) Myanmar: USDP-Led Coalition Calls on Govt to Reject Rohingya Ethnicity.

49. Myanmar revokes Rohingya voting rights after protests (2015).

50. Burma's Troublesome Census (2012).

51. Rohingya Briefing Report. War Zone Initiatives (2015).

52. Berlinger, KH (2017) Aung San Suu Kyi Breaks Silence on Rohingya, Sparks Storm of Criticism.

53. Ekin A (2017) Rohingya refugees share stories of sexual violence.

54. Gladstone R (2017) Rohingya Were Raped Systematically by Myanmar's Military, Report Says.

55. Kiener R (2012) Myanmar's New Era, Will the military allow reforms to continue? C Q Researcher. pp: 329-352.

56. Kramer T (2012) Ending 50 years of military rule? Prospects for peace, Norway: NOREF.

57. Crossman L (2014) Myanmar's Rohingya Refugees. Washington DC: Georgetown University.

58. Martin MF (2017) Burma's Brutal Campaign Against the Rohingya. New York Congressional Research Service.

59. Myanmar military exonerates itself in report on atrocities against Rohingya (2017).

60. Nelson MJ (2016) Local Orders \& International Engagement. Local Orders, pp: 1-17.

61. Payne E (2015) Aung San Suu Kyi's NLD wins historic majority in Myanmar election.

62. Rohingya 'extremists' trying to build stronghold - Myanmar army (2017).

63. Rohingya refugees have been fleeing violence in Myanmar at a staggering rate - and the numbers keep growing (2017).

64. Schuler KO (2015) Myanmar's Landmark Election: Unresolved Questions ISEAS Yuof Ishak Institute. 